\title{
Re-examining the problems of long-term imprisonment
}

\section{Susie Hulley, Ben Crewe and Serena Wright}

Institute of Criminology, University of Cambridge, Sidgwick Avenue, Cambridge, CB3 9DA.

\begin{abstract}
Drawing on an amended version of a survey employed in three previous studies, this article reports the problems experienced by 294 male prisoners serving very long life sentences received when aged 25 or under. The broad findings are consistent with previous work, including few differences being found between the problems experienced as most and least severe by prisoners at different sentence stages. By grouping the problems into conceptual dimensions, and by drawing on interviews conducted with 126 male prisoners, we seek to provide a more nuanced analysis of this pattern. We argue that, while earlier scholars concluded that the effects of long-term confinement were not 'cumulative' and 'deleterious', adaptation to long-term imprisonment has a deep and profound impact on the prisoner, so that the process of coping leads to fundamental changes in the self, which go far beyond the attitudinal.
\end{abstract}

\section{Keywords}

Long-term imprisonment, pains of imprisonment, life sentence.

Despite differences in trends internationally, there is broad agreement among penologists that recent years have seen a hardening of penal sensibilities in Western nations, resulting in increasingly severe sentencing and penal practices (e.g. Feeley and Simon 1992; Hough, Jacobson and Millie 2003; Wacquant 2009). In the UK, these developments are manifested in the length of indeterminate sentences for serious offences. The 2003 Criminal Justice Act introduced a range of mandatory minimum custodial 'starting points' (i.e. 'tariffs') for a range of homicide offences: murder involving the use of a firearm or explosive, for example, now attracts a sentencing starting point of 30 years; for offenders convicted of murder when aged under 18, the minimum starting point was raised to 12 years. Latterly, partly in response to media-led calls for tougher sentences for 'knife crime', the minimum term for murders by adults (aged 18 or over) involving weapons taken to the scene with the intention of use has been increased (by 10 years) to 25 years. The impact of such changes is evident: the minimum term imposed on those sentenced to life between 2003 and 2013, excluding whole life tariffs, increased from 12.5 to 21.1 years. ${ }^{1}$ As a result, there are a growing number of prisoners serving sentences that were almost unheard of a generation ago.

Existing literature on the impact of these increasingly long, indeterminate sentences on those who are serving them is dated or of limited applicability. In the US, considerable scholarly attention has been devoted to 'super-max' incarceration (e.g. Rhodes 2004; King 2005), but the particularly 'bleak' and restrictive conditions of solitary confinement (Johnson and McGunigallSmith 2008: 331) mean that such prisoners' experiences are likely to be notably different from long-term prisoners in England and Wales. And while research on prisoners sentenced to 'Life Without Parole' (LWOP) in the US offers some insight into problems associated with serving a long, indeterminate sentence (see Johnson and McGunigall-Smith 2008), the absence of any

\footnotetext{
${ }^{1}$ Information obtained from Ministry of Justice by Jonathan Bild, Faculty of Law, University of Cambridge - Freedom of Information request FOI/89346, April 2014
} 
realistic hope of release is, likewise, far removed from the experience of serving a long sentence with a theoretical endpoint. In the UK, research on long-term confinement has diminished considerably since the 1970s-80s (Cohen and Taylor 1972; Sapsford 1983; Bukstel and Kilmann 1980; Walker 1987) when studies reported that male long-termers were primarily concerned about their lack of privacy, the loss of contact with loved ones and the possibility of mental deterioration. $^{2}$ A small number of more recent studies offer qualitative insight into the experiences of long-term and life-sentenced prisoners in the UK (e.g. Jewkes 2005; Crawley and Sparks 2006; Schinkel 2014), and high-security prisons (Liebling, Arnold and Straub 2012; Liebling and Arnold 2012), but our understanding of contemporary experiences of long-term confinement remains extremely limited.

Exceptionally, a series of studies conducted during the last 40 years have attempted to assess the problems of long-term imprisonment in both the US and UK using a standardised measure (Richards 1978; Flanagan 1981; Leigey and Ryder 2014). Despite the inevitable limitations associated with the contextual disparities and methodological differences between these studies and the absence of female prisoners in all the studies, they provide a rare insight into the problems experienced by male prisoners serving long sentences and allow for (cautious) comparisons to be made across time and place.

Each of these three studies used a survey instrument developed by Richards (1978: 163) in the first study in the series. Richards' survey contained 20 'problem statements', thought to represent 'most of the areas of psychological stress experienced by the long-term prisoner'. For each problem, the respondent was asked 'How often do you get this problem?' (measured as 'Frequency' on a Likert scale of 1-5, where 1 was 'never' and 5 was 'very often') and then, 'When you get this problem, how easy is it to deal with?' (measured as 'Intensity' on a Likert scale of 15 , where 1 was 'very easy' and 5 was 'very difficult'). A 'Severity' score for each problem was calculated as 'Frequency' multiplied by 'Intensity' (F x I) (Richards 1978: 163). The 'Intensity' score for those who selected 'never' in response to the former question was reported as ' 0 ', so that the corresponding Severity score was also $0(1 \times 0)$. Thus, Severity scores ranged from 0 25 for each 'problem', where 0 was the least severe and 25 was the most severe.

Richards administered the survey to 22 male prisoners in one high security prison in the UK, serving life-sentences or determinate sentences of at least 10 years. The five most severe problems reported by the prisoners were (in order, with the most severe first): 'missing someone', 'feeling that your life is being wasted', 'feeling sexually frustrated', 'missing little luxuries', and 'missing social life' (see Table 4 in the Results section). Most represented what Richards called 'Outside' problems, relating to the 'deprivation of relationships with and in the outside and the loss of a full role repertoire' (Richards 1978: 167, emphasis in original), rather than 'Inside' problems, which related primarily to experiences 'inside of the prison per se' (Richards 1978: 164). Although many of the most severe problems reflected the 'pains of imprisonment', as documented by Sykes (1958), including the deprivation of liberty, the deprivation of goods and services and the deprivation of heterosexual relationships, Flanagan in the subsequent study of the series - noted that the extraordinary length of time for which

\footnotetext{
2 'There is no uniform definition of 'long-term' incarceration (Flanagan 1995: 4). Various definitions are applied in empirical research from, for example, as little as four years (Schinkel 2014) to whole lifesentences (or Life Without Parole - LWOP - in the US) (Johnson and McGunigall-Smith 2008). For the purpose of our study, long prison sentences were defined as life-sentences with a tariff of 15 years and over.
} 
these deprivations were experienced was likely to render them more 'critical' for the long-term prisoner (Flanagan 1981: 210).

A number of the problems experienced as the 'least severe' by prisoners in Richards' study were related to mental health issues Thus, Richards (1978: 167) concluded that prison was not 'experienced by most of these men as a fundamental threat to their mental health'. Subsequent support for such claims has been mixed (see Rasch 1981; Dettbarn 2012; Lapornik et al 1996; Sapsford 1983; Cohen and Taylor 1972).

As part of his original article, Richards (1978) considered differences over time by comparing the results of two matched groups of 11 male prisoners, selected during the sampling process: a 'late' group, who had served at least eight years and an 'early' group, who had served less than 18 months. 'Being bored' was amongst the five most severe problems for the early group only, and 'getting annoyed or irritated with other prisoners' was amongst the five most severe problems for the late group only. Other than this, though, the most severe problems were shared. This is perhaps surprising, given the literature on the experiences of prisoners more generally. The early stage of imprisonment has been associated with higher levels of distress (Liebling et al 2005b), as prisoners experience the 'sudden dislocation from a previous life' (Liebling et al 2005a: 225). This period may be particularly difficult for prisoners sentenced to life, who Sapsford (1983) described as showing a period of emotional 'floundering" as they confronted profound changes in their circumstances, self-image and sense of the future. Still, the similarities between the two groups of prisoners at different sentence stages in Richards' study led him to conclude that 'prison does not necessarily have cumulative or progressive effects on prisoners' experience of its inherent problems' (Richards 1978: 166).

In the second study of the series, Flanagan (1980: 149) replicated Richards' survey with 49 men in five maximum security prisons in the US, who had served 'at least five years of continuous confinement'. There were remarkable similarities between Flanagan's and Richards' findings, despite the geographical and methodological differences between their studies. 'Outside' problems were again experienced as significantly more severe than 'Inside' problems (for further details, see Table 4). Only 'worrying about how you will cope when you get out' differentiated Flanagan's five most severe problems from Richards' (who found this to be the tenth most severe problem in his study).

There were similarities too in the five least severe problems, with concerns about mental health - 'being afraid of going mad', 'losing your self-confidence' and 'feeling suicidal' - featuring in both sets of findings. Like Richards, Flanagan (1980: 152) claimed that the results demonstrated the lack of deleterious effects of long-term imprisonment, in fact: 'several of these men reported that being in prison had in some way strengthened their resolve and that they were emotionally, physically and intellectually stronger as a result' (emphasis added). The potential for flourishing among long-term prisoners has been reported elsewhere (Rasch 1981; van Ginneken 2014; O'Donnell 2014). This reflects research on 'post-traumatic growth', which argues that traumatic events, such as bereavement and accidents, can produce positive change and lead to a 'higher level of functioning' (Hefferon, Grealy and Mutrie 2009: 343). Such evidence negates a longstanding area of literature, that links traumatic events to 'severe and complex psychological reactions', and in some cases a 'constellation of clinical features', known as Post Traumatic Stress Disorder (PTSD) (Grounds 2005: 13). Indeed, in their recent study of long-term prisoners post release (discussed further below), Liem and Kunst (2013) found evidence of 
PTSD symptoms amongst their participants, as well as a cluster of additional psychological problems associated with long-term imprisonment.

The third, and most recent, application of Richards' survey was undertaken by Leigey and Ryder (2014), in a study of 18 male prisoners serving Life Without Parole (LWOP) in one state in the US. Again, similarities with the previous studies were found despite the particular sentence type and the distinctive lack of hope such prisoners are likely to experience (cf. Johnson and McGunigall-Smith 2008). 'Outside' problems were rated as more severe than 'Inside' problems. Although 'missing somebody' was not reported as the most severe problem, it was ranked third and, as in the previous studies, 'missing social life' and 'feeling that your life is being wasted' were among the five most severe problems (see Table 4). The most severe problem for the LWOP prisoners was 'missing little luxuries' which, along with 'wishing you had more privacy', featured across all three studies, suggesting that these are aspects of all forms of long-term confinement, rather than specific to life without parole. Similarly, three of the five least severe problems suggested that mental health problems were not a particular concern for this sample either. This pattern appeared in all three of the studies. Strong levels of agreement in the most and least severe problems were found between prisoners in Leigey and Ryder's sample who had served more than the average sentence length (30.5 years) and those who had served less than the average, which - similar to Richards (1978) - was interpreted as indicating that these problems did not feel worse over time.

Each of these studies has limitations, and there are a number of problems with comparing their outputs. In Richards' (1978) and Leigey and Ryder's (2014) studies, in particular, the sample size is small, particularly when comparisons are made between groups (each group included fewer than 12 prisoners in both studies - see Tables 1 and 3, below, for further details). The sampling differences between the groups are imperfect for the purpose of comparative evaluations, with prisoners serving different sentences, from as short as five years of continuous confinement to LWOP (although, given these differences, the similarities between the findings are perhaps more remarkable). More generally, both Flanagan and Richards (cited in Flanagan 1980: 152) recognised the potential for prisoners to moderate their responses regarding the extent to which problems were troubling, due to expectations of masculinity, specifically, the imperative to be seen to be coping. Still, for the purpose of this paper, two findings from across all three studies are of particular importance: firstly, the consistency between the problems reported as severe at different sentence stages; and secondly, the conclusion that the effects of imprisonment are not accumulative.

This paper reports the findings from the administration of an extended version of Richards' (1978) survey instrument with male prisoners, which formed part of a broader study of men and women serving very long life-sentences, which they received when young. For comparative purposes, this paper focuses on the data from the male sample, given that the participants in all previous studies were men (the data from the female participant will be reported elsewhere). The results show remarkable similarities in the most and least severe problems reported in the previous studies and relatively few significant differences between prisoners at different sentence stages. However, by grouping the problems into conceptual dimensions, we show that different 'types' of problem tend to be experienced by long-term prisoners as more or less severe at different sentence stages. This leads us to challenge previous findings which play down the potential negative, cumulative impact of incarceration, and conclude instead that the modes of adaptation developed by prisoners to cope with the demands of long-term 
confinement may alter them in fundamental ways, which may well be 'maladaptive' and counter-productive for life on release (Grounds 2005; Haney 2003; Liem and Kunst 2013).

\section{The current study}

The study focused on men and women serving life-sentences, with a tariff (minimum sentence) of 15 years or more, received when aged 25 years or younger. Data provided by the National Offender Management Service revealed that, at the start of the fieldwork period, in February 2013, there were 808 prisoners in England and Wales who matched the research criteria, of whom 789 were men, held in 73 prison establishments.

In total, 309 men (39\% of the male population who matched the research criteria) participated in the study. Participants were drawn from 16 prisons in England, primarily those holding 1\% or more of the target population (21 prisons held at least $1 \%$ of the population $-81.4 \%$ of the total population of our sample were held in these 21 establishments), so that as many prisoners as possible could be accessed with each fieldwork visit. Specific prisons were selected based on access and size of sample (with prisons with the largest representation of prisoners, who met our criteria, being prioritised). Three prisons that held fewer than $1 \%$ were included in the sample, in order to access prisoners at the end of their sentences, serving time in Category D 'open' prisons (given the increase in the length of life-sentence tariffs over the last ten years, relatively few prisoners who were towards the end of very long sentences fitted our specific criteria). Prisons were selected to broadly represent the proportion of life-sentenced prisoners who fitted our criteria, and who resided in each of the categories of prison (Young Offender Institutions, High Security, Category B, C and D).

A mixed methods design was adopted in the study, comprising surveys with 294 prisoners and in-depth interviews with 126 prisoners. ${ }^{3}$ This paper reports primarily on the findings of the survey, with reference to the findings from the prisoner interviews, where pertinent to the argument being made in the discussion (see Crewe et al, in progress and Wright et al, under review, for more details of the other aspects of the research).

\section{Surveys}

Questionnaires were administered in 16 prisons, with all prisoners who met our criteria being considered eligible for participation. While practices varied a little in each prison (often due to the operational demands of the particular establishment), typically, all prisoners were approached in person by one of the researchers who explained the purpose of the research. Due to the sensitivity of the subject matter, participants were left with an information sheet for twenty-four hours to consider participation. Prisoners were then revisited and - if amenable to taking part - given a survey, where verbal consent was obtained. Surveys were provided inside sealable envelopes, which also contained the information sheet, an informed consent form (that all prisoners signed) and a 'support note' which signposted prisoners to available support should they wish to talk to someone as a result of carrying out the survey. Due to the potentially emotional nature of the survey, we ensured that prisoners never retained the survey overnight. While levels of literacy among prisoners are known to be lower than among their non-prisoner

\footnotetext{
${ }^{3}$ There was a high level of correspondence between those prisoners who completed an interview and a survey (112 prisoners) - 14 prisoners completed only an interview and 183 prisoners completed only a survey.
} 
counterparts (Prison Reform Trust 2014), when asked (as all were), few prisoners presented themselves as being unable to complete the survey autonomously. Where literacy issues were highlighted, a member of the research team supported the prisoner by presenting the questions orally. On completion of the survey, a short debrief was held with each prisoner to ensure they were not emotionally troubled by the exercise. In only two cases, prisoners requested more extensive discussions with the research team due to the difficult nature of the survey.

The survey instrument replicated that used by Richards (1978), Flanagan (1980) and Leigey and Ryder (2014) with some adaptations and significant additions, outlined below. For that reason, in Table 1, we provide a summary of the methodological details of the study alongside those of the comparative studies in which this research instrument was also adopted. The table shows the breadth of our research compared to previous studies, both in terms of the range of prisons included and the number of prisoners who participated. It also highlights the differences in the definition of 'long-term imprisonment' used in each study, from five years of continuous confinement, to life-sentences with minimum terms of 15 years minimum. Given such disparities, the similarities between the results of each study are particularly noteworthy.

Table 1 - Location and context of the current survey (highlighted) compared to previous studies using the same research instrument.

\begin{tabular}{|c|c|c|c|c|c|}
\hline & $\begin{array}{c}\text { Geographic } \\
\text { location }\end{array}$ & $\begin{array}{c}\text { No. of } \\
\text { prisons }\end{array}$ & Prison type/s & Sentence length & $\begin{array}{c}\text { No. of } \\
\text { participants }\end{array}$ \\
\hline $\begin{array}{c}\text { Current study } \\
(2013-2014)\end{array}$ & UK & 16 & $\begin{array}{c}\text { Young Offenders } \\
\text { Institutions } \\
\text { High Security } \\
\text { Category B } \\
\text { Category C } \\
\text { Category D }\end{array}$ & $\begin{array}{c}\text { Life-sentence } \\
\text { with tariff of 15 } \\
\text { years or more }\end{array}$ & 294 \\
\hline $\begin{array}{c}\text { Richards } \\
(1978)\end{array}$ & UK & 1 & High security & $\begin{array}{c}\text { At least 10 years } \\
\text { or life }\end{array}$ & 22 \\
\hline $\begin{array}{c}\text { Flanagan } \\
(1980)\end{array}$ & US & 5 & Maximum security & $\begin{array}{c}\text { Served at least 5 } \\
\text { years of } \\
\text { continuous } \\
\text { confinement }\end{array}$ & 49 \\
\hline $\begin{array}{c}\text { Leigey and } \\
\text { Ryder (2014) }\end{array}$ & US & Unknown & Unknown & $\begin{array}{c}\text { Served at least 15 } \\
\text { years of a life } \\
\text { without parole' } \\
\text { (LWOP) sentence }\end{array}$ & 18 \\
\hline
\end{tabular}

\section{Development of the survey instrument}

For the purpose of this study, two of the 20 problems presented to prisoners in the survey used by Richards (1978), Flanagan (1980), and Leigey and Ryder (2014) were removed and the wording of two further problems was changed. 'Being worried about becoming a vegetable' was removed due to its outdated language, while 'longing for a time in the past' was removed because it seemed vague and unclear. 'Keeping out of trouble' was changed to 'finding it hard keeping out of trouble', to fit with the wording of other problem statements, and 'being afraid of 
going mad' was changed to 'worrying about my mental health', again to reflect more appropriate language.

Towards the end of the seven week fieldwork period in the first prison, prior to any surveys being undertaken, additional statements were developed to represent problems that prisoners reported in our initial wave of interviews but that did not feature in Richards' original survey. For example, a number of items relating to the 'tightness' of contemporary imprisonment (Crewe 2011) - the role of specialist staff and risk assessment practices in determining prisoner progression - were devised in order to address issues that prisoners were telling us were particularly pertinent to contemporary imprisonment. These included problems such as: 'worrying about how you are described on file' and 'feeling you have to be careful about everything you say or do'. Others reflected concerns about personal autonomy, for example: 'feeling you have no control over your life' and 'having to follow other people's rules and orders'. In total, 21 problem statements were added to the survey meaning that prisoners were asked to consider 39 potential problems of long-term imprisonment overall, as shown in Table 2.

For the purpose of the current study, the problems were not separated into 'outside' and 'inside' problems as this was considered to offer limited benefits to the process of analysis. We agreed with Richards' (1978: 166) own critique, that the distinction made between these categories was 'crude', particularly in relation to some of the original problems such as 'feeling sorry for yourself' and 'wishing that time would go faster'. This was also the case for many of the supplementary problems such as 'feeling that you have no-one to talk to about the things that really matter to you' and 'feeling lonely', which might easily fall into either or both categories. Instead we attempted to make more precise distinctions between problems, post hoc, by grouping problems thematically and statistically into a number of dimensions (see results below).

\section{Survey analysis}

As with the previous studies, participants in the current study were asked to score each problem on a 'Frequency' (F) scale (reporting how 'often' they experienced the problem, on a Likert scale from 1-5, where 1 was 'never' and 5 was 'very often') and on what Richards (1978), Flanagan (1980) and Leigey and Ryder (2014) called an 'Intensity' (I) scale. As this asked prisoners to report 'how easy' the problem was to 'deal with' when it was experienced (on a Likert scale of 1-5, where 1 was 'very easy' and 5 was 'very difficult'), we replaced the term Intensity with the more intuitively accurate term 'Solubility' (Sol): how soluble, or solvable, the problem was felt to be. As such, problem 'Severity' (Sev) was calculated by multiplying the Frequency score by the Solubility score (F x Sol = Sev) (note that, as in the previous studies, where prisoners reported 'never' experiencing the problem, the Severity score was 0). As with the previous studies, mean Severity scores ranged from 0-25. 
Table 2 - Richards' (1978) original problem statements (as revised) and additional problem statements included in the current study

\begin{tabular}{|c|c|}
\hline $\begin{array}{l}\text { Richards' (1978) problem statements } \\
\text { (with revised wording shown in italics) }\end{array}$ & $\begin{array}{c}\text { Additional problem statements included } \\
\text { in the current study }\end{array}$ \\
\hline Wishing that time would go faster & $\begin{array}{l}\text { Feeling that you are losing the best years of } \\
\text { your life }\end{array}$ \\
\hline Wishing you had more privacy & $\begin{array}{l}\text { Feeling that the system is ignoring you and } \\
\text { your individual needs }\end{array}$ \\
\hline Feeling that your life is being wasted & Thinking about the crime that you committed \\
\hline Losing your self-confidence & $\begin{array}{l}\text { Feeling that you are losing contact with family } \\
\text { and friends }\end{array}$ \\
\hline Feeling sorry for yourself & Prison officers making life harder \\
\hline $\begin{array}{l}\text { Missing little" luxuries ", e.g. your favourite } \\
\text { food, home comforts }\end{array}$ & Feeling that you have no control over your life \\
\hline $\begin{array}{l}\text { Finding it hard keeping out of trouble (replaced } \\
\text { 'keeping out of trouble') }\end{array}$ & $\begin{array}{l}\text { Not feeling able to completely trust anyone in } \\
\text { prison }\end{array}$ \\
\hline Feeling angry with yourself & Prison psychologists making life harder \\
\hline Missing social life & $\begin{array}{l}\text { Feeling that the length of your sentence is } \\
\text { unfair }\end{array}$ \\
\hline Feeling suicidal & Feeling lonely \\
\hline Feeling angry with the world & Feeling worried about your personal safety \\
\hline Missing somebody & $\begin{array}{l}\text { Feeling frustrated that you are not progressing } \\
\text { through the system }\end{array}$ \\
\hline $\begin{array}{l}\text { Getting annoyed or irritated with other } \\
\text { prisoners (replaced 'inmates') }\end{array}$ & Worrying about people outside \\
\hline Being afraid of dying before you get out & $\begin{array}{l}\text { Feeling that you have no purpose or meaning } \\
\text { in your life }\end{array}$ \\
\hline Feeling sexually frustrated & Worrying about how you are described 'on file' \\
\hline $\begin{array}{l}\text { Being worried about my mental health } \\
\text { (replaced 'being afraid of going mad') }\end{array}$ & $\begin{array}{l}\text { Feeling anxious about the uncertainty of your } \\
\text { release date }\end{array}$ \\
\hline $\begin{array}{l}\text { Worrying about how you will cope when you } \\
\text { get out }\end{array}$ & $\begin{array}{l}\text { Feeling that you have no-one to talk to about } \\
\text { things that really matter to you }\end{array}$ \\
\hline Being bored & $\begin{array}{l}\text { Thinking about the amount of time you might } \\
\text { have to serve }\end{array}$ \\
\hline & $\begin{array}{l}\text { Having to follow other people's rules and } \\
\text { orders }\end{array}$ \\
\hline & $\begin{array}{l}\text { Feeling that you need to be careful about } \\
\text { everything you say and do }\end{array}$ \\
\hline & $\begin{array}{l}\text { Being afraid that someone you love or care } \\
\text { about will die before you are released }\end{array}$ \\
\hline
\end{tabular}

Survey sample

The basic demographics of the survey sample in this study are shown in Table 3, alongside those of the samples in the comparative studies. The table shows differences in sentence stages, mean age at study, mean age at sentence, and in the ethnic make-up of each study sample. It also shows that, for the purpose of analysis, the survey sample in this study was split into five groups, in order to capture each sentence stage and compare the results between them. Sentence stage was calculated based on the proportion of their own tariff each individual had served. The earliest stage was split into two groups because of the large number of prisoners 
who were in this part of their sentence. The reasons for this are twofold. Firstly, nationally, a larger proportion of prisoners are at the earlier stages of these sentences (because sentence lengths have increased). Secondly, we deliberately oversampled prisoners at the early stage as we hope to revisit prisoners at five-yearly intervals to resurvey them and this means there will be a large cohort of prisoners we can follow through their sentences. Due to this skew in the sample profile, the 'very early', 'early' and 'mid' stage prisoners outnumber the 'late' and 'post tariff groups. This has implications for the results, as described below.

\section{Interviews}

Interviews were conducted with prisoners at 15 men's prisons. The interviews comprised two parts. The first was a 'life history' interview (e.g. Holloway \& Jefferson 2000; McAdams 1988), which asked prisoners for auto-biographical information about their early life, including their relationships with family and experiences of education, authority and official agencies. The second asked prisoners about their 'life inside' prison, since being convicted of their current lifesentence. This interview explored issues such as, how the individual psychologically managed their sentence, their thoughts on identity, change and future, how they socially adapted within the prison and their thoughts on the legitimacy of their conviction and their sentence.

Prisoners were sampled purposively, based on their sentence stage, to allow for the analysis to focus on prisoners' experiences at the early, mid and late stages of such very long life-sentences. In this context, 'early' stage was defined as within four years of conviction date (i.e. not remand date), 'mid' stage was calculated as the mid-point of each individual's tariff length, plus or minus two years, and 'late' stage was defined as within two years of tariff date or over tariff. In total, 126 prisoners participated in interviews: 60 were at the 'early' stage; 36 at the 'mid' stage; and 29 at the 'late' stage.

\section{Methodological issues}

A methodological difficulty in relation to the analytical groupings, used for the survey analysis and interview sampling, is that due to the cross sectional nature of the study, we cannot draw strong conclusions about 'change' over the course of the sentence. Indeed, there is considerable potential for cohort effects, not least because it has become far more typical in recent years for people receiving life-sentences to be given very long tariffs than it was when our late stage prisoners were sentenced. Among our survey respondents, for example, compared to the 'PostTariff' group 'Very Early' prisoners were: eight times more likely to be serving sentences of 20 years of more; 15.5 times more likely to be denying their guilt; and 2.8 times more likely to be Black or from a minority ethnic group (the difference between groups on each of these variables was significant). ${ }^{4}$ Moreover, particular differences between prisoners in the Post-Tariff stage and those in the other groups may also reflect a methodological limitation related to the concept of 'selective release' (Zamble 1992); that is, that prisoners who remain in prison beyond their tariff may be different to those who gain release, and thus not directly comparable. Period effects may also affect the experiences of the different groups of prisoners, in that more punitive and austere penal sensibilities may differentially impact on the experience of the life-sentence for those who experience it during particular eras. Establishing the contribution of period and

\footnotetext{
${ }^{4}$ There was a significant association between sentence stage and: tariff length (defined as under 20 years or 20 years and over $\left.-\chi^{2}(4)=53.29, p<0.001\right)$; guilt $\left(\chi^{2}(4)=36.74, p<0.001\right)$; and ethnicity $\left(\chi^{2}(4)=12.55\right.$, $p<0.05)$.
} 
cohort effects is complicated, however, and the similar results across the various studies undertaken over 40 years suggest that the impact of such issues on the results may be small, as will be discussed below. Age effects suggest that older prisoners (i.e. those in the Late and PostTariff groups) may have adapted to prison due to their age and that their adaptive techniques may be different to those used by younger prisoners as they progress through their sentence.

\section{Results}

When comparing only the original problem statements, the results from our study showed considerable consistency with previous findings (Richards 1978, Flanagan 1980 and Leigey and Ryder 2014). Like the men in Richards' (1978) and Flanagan's (1980) studies, the prisoners who participated in our survey reported 'missing somebody' to be the most severe problem. Despite slight differences in sequencing, the five most severe problems in the current study replicated those in Richards' study exactly (see Table 4). Concerns about loved ones, the pains associated with basic deprivations (social life, luxuries and sexual relations) and the loss of a 'useful' or 'productive' life remained the most severe. Once the supplementary problems, added for the purpose of the current study, were taken into account, three new 'most severe' problems emerged. Two of these reflected the same underlying themes of those they replaced: concerns for others outside of prison ('worrying about people outside') and the loss of a good life ('feeling that you are losing the best years of your life'), whilst the other - ('having to follow other people's rules and order') represented another established 'pain of imprisonment' - the loss of autonomy (Sykes 1958).

While previous research suggested that mental deterioration (Cohen and Taylor 1972) and emotional vulnerability were at the forefront of long-term prisoners' minds, the results from our study suggested otherwise - as found in Flanagan's, Richards', and Leigey and Ryder's studies (although Flanagan (1981) later reported, based on interviews with prisoners, that fear of deterioration was one of only three 'attitudinal' changes that occurred among long-term prisoners). Feeling suicidal and being afraid of going mad ('being worried about my mental health' in our study) featured amongst the least severe problems in all four studies (see Table 4).

Similarly the presence of 'being afraid of dying before you get out' and 'feeling sorry for yourself within the five least severe problems mirrored findings in the previous studies. 'Feeling angry with the world' appeared in the five least severe problems in all studies apart from Flanagan's (1980). 'Being worried about my personal safety' was the only additional problem to feature in the five least severe problems in our study, once the supplementary problems were included in the analysis. 
Table 3 - Demographic details of survey sample in current study compared to previous comparative studies

\begin{tabular}{|c|c|c|c|c|}
\hline & Sentence stage of participants & $\begin{array}{l}\text { Age range of } \\
\text { participants } \\
\text { at study } \\
\text { (mean) } \\
\text { in years }\end{array}$ & $\begin{array}{l}\text { Mean age at } \\
\text { sentence in years }\end{array}$ & $\begin{array}{c}\text { Ethnicity } \\
\text { (as proportion of total } \\
\text { sample) }\end{array}$ \\
\hline $\begin{array}{l}\text { Current } \\
\text { study } \\
(2014)\end{array}$ & $\begin{array}{l}\text { All stages. } \\
\text { During analysis, the sample was split into the following groups: } \\
\text { Very Early - served up to first sixth of sentence: } n=58 \\
\text { Early - served between one sixth and two sixths - or a third - of sentence: } n=100 \\
\text { Mid - served more than one third but less than two thirds of sentence: } n=86 \\
\text { Late - served two thirds or more of sentence but less than tariff length: } n=27 \\
\text { Post-tariff - served tariff length or were passed tariff date: } n=20\end{array}$ & $\begin{array}{l}18-67 \\
(28.5)\end{array}$ & $\begin{array}{l}20.7 \\
\text { Very early }-20.8 \\
\text { Early }-20.4 \\
\text { Mid }-20.7 \\
\text { Late }-20.9 \\
\text { Post-tariff }-21.0\end{array}$ & $\begin{array}{l}\text { - } 50.2 \% \text { White } \\
\text { - } 28.7 \% \text { Black } \\
\text { - } 11.9 \% \text { 'Mixed race' } \\
\text { - } 6.1 \% \text { Asian } \\
\text { - } 3.0 \% \text { 'other ethnic } \\
\text { group' }\end{array}$ \\
\hline $\begin{array}{c}\text { Richards } \\
\text { (1978) }\end{array}$ & $\begin{array}{l}\text { Early - served less than } 18 \text { months: } n=11 \text { ( } 8 \text { 'lifers', } 3 \text { 'fixed term') } \\
\text { Late - served at least } 8 \text { years: } n=11 \text { ( } 7 \text { 'lifers', } 4 \text { fixed term) }{ }^{5}\end{array}$ & Not detailed & $\begin{array}{l}\text { Early: } 32 \\
\text { Late: } 28\end{array}$ & Not detailed \\
\hline $\begin{array}{c}\text { Flanagan } \\
(1980)\end{array}$ & Mean time served on sentence 7.9 years (95 months) & $(31)$ & 23 & $\begin{array}{l}\text { - 'more than half were } \\
\text { black' (p.149) } \\
\text { - } 29 \% \text { White, } \\
\text { - } 15 \% \text { 'other', } \\
\text { 'primarily Puerto } \\
\text { Rican' } \\
\end{array}$ \\
\hline $\begin{array}{l}\text { Leigey } \\
\text { and } \\
\text { Ryder } \\
(2014) \\
\end{array}$ & $\begin{array}{l}\text { Time served } 20-37 \text { years. } \\
\text { Mean time served } 30.5 \text { years. 'Old Timers' }(n=7) \text { - served less than the mean } \\
\text { time. 'Advanced Old Timers' }(n=11) \text { - served longer than the mean time. }\end{array}$ & $\begin{array}{l}55-73 \\
(62.4)\end{array}$ & Not detailed & $\begin{array}{l}\text { - } 38.9 \% \text { White } \\
\text { - } 61.1 \% \text { 'minorities' } \\
\text { ('almost all of whom } \\
\text { were Black') (p.6) }\end{array}$ \\
\hline
\end{tabular}

${ }^{5}$ Note: The participants in the early and late group were matched 'as far as possible' on the following criteria: age at sentencing (under or over 25 years); sentence (life or fixed term); type of offence (domestic murder, other murder/manslaughter, sex offence involving children, other sex offence, 'professional' crime) (Richards 1978: 162). 
Table 4 - Comparison of the five 'most severe' and five 'Ieast severe' problems in previous studies and current study

\begin{tabular}{|c|c|c|c|c|}
\hline Richards (1978) & Flanagan (1980) & Leigey and Ryder (2014) & $\begin{array}{c}\text { Current study (2014) } \\
\text { Richards' original problems } \\
\text { only (with two removed) }\end{array}$ & $\begin{array}{c}\text { Current study (2014) } \\
\text { All problems in survey }\end{array}$ \\
\hline \multicolumn{5}{|l|}{ Most severe problems } \\
\hline $\begin{array}{l}\text { 1. Missing somebody } \\
\text { 2. Feeling that your life is } \\
\text { being wasted } \\
\text { 3. Feeling sexually } \\
\text { frustrated } \\
\text { 4. Missing little 'luxuries' } \\
\text { 5. Missing social life }\end{array}$ & $\begin{array}{l}\text { 1. Missing somebody } \\
\text { 2. Missing social life } \\
\text { 3. Worrying about how } \\
\text { you will cope when you } \\
\text { get out } \\
\text { 4. Feeling that your life is } \\
\text { being wasted } \\
\text { 5. Feeling sexually } \\
\text { frustrated }\end{array}$ & $\begin{array}{l}\text { 1. Missing little 'luxuries' } \\
\text { 2. Missing social life } \\
\text { 3. Missing somebody } \\
\text { 4. Feeling that your life is } \\
\text { being wasted } \\
\text { 5. Wishing you had more } \\
\text { privacy }\end{array}$ & $\begin{array}{l}\text { 1. Missing somebody } \\
\text { 2. Feeling that your life is } \\
\text { being wasted } \\
\text { 3. Missing social life } \\
\text { 4. Missing little 'luxuries' } \\
\text { 5. Feeling sexually } \\
\text { frustrated }\end{array}$ & $\begin{array}{l}\text { 1. Missing somebody } \\
\text { 2. Worrying about people } \\
\text { outside } \\
\text { 3. Feeling that you are } \\
\text { losing the best years or } \\
\text { your life } \\
\text { 4. Having to follow other } \\
\text { people's rules and } \\
\text { orders } \\
\text { 5. Feeling that your life } \\
\text { has been wasted }\end{array}$ \\
\hline \multicolumn{5}{|l|}{ Least severe problems } \\
\hline $\begin{array}{l}\text { 16. Losing your self- } \\
\text { confidence } \\
\text { 17. Feeling angry with the } \\
\text { world } \\
\text { 18. Being afraid of dying } \\
\text { before you get out } \\
\text { 19. Being afraid of going } \\
\text { mad } \\
\text { 20. Feeling suicidal }\end{array}$ & $\begin{array}{l}\text { 16. Keeping out of trouble } \\
\text { 17. Feeling sorry for } \\
\text { yourself } \\
\text { 18. Being afraid of going } \\
\text { mad } \\
\text { 19. Losing your self- } \\
\text { confidence } \\
\text { 20. Feeling suicidal }\end{array}$ & $\begin{array}{l}\text { 16. Being afraid of going } \\
\text { mad } \\
\text { 17. Feeling sorry for } \\
\text { yourself } \\
\text { 18. Losing your self- } \\
\text { confidence } \\
\text { 19. Feeling angry with the } \\
\text { world } \\
\text { 20. Feeling suicidal }\end{array}$ & $\begin{array}{l}\text { 14. Being afraid of dying } \\
\text { before you get out } \\
\text { 15. Feeling sorry for } \\
\text { yourself } \\
\text { 16. Being worried about } \\
\text { my mental health } \\
\text { (replaced 'being afraid } \\
\text { of going mad') } \\
\text { 17. Feeling angry with the } \\
\text { world } \\
\text { 18. Feeling suicidal }\end{array}$ & $\begin{array}{l}\text { 35. Feeling sorry for } \\
\text { yourself } \\
\text { 36. Feeling worried about } \\
\text { your personal safety } \\
\text { 37. Being worried about } \\
\text { my mental health } \\
\text { 38. Feeling angry with the } \\
\text { world } \\
\text { 39. Feeling suicidal }\end{array}$ \\
\hline
\end{tabular}


Examining the overall severity of the 39 problems presented in our study by 'sentence stage', we found relatively few significant differences between prisoners' assessments of each problem, as in Richards' (1978) study, although scores tended to be in the same direction of travel higher at the earliest stage and decreasing at each stage thereafter. Significant differences between groups were found in 14 out of 39 problems. In almost all cases this reflected differences between the Post-Tariff group and one or more of the other groups of prisoners earlier in their sentence. However, within this general pattern of declining or relatively consistent problem severity by sentence stage, our analysis suggests a more complex and subtle pattern of results. Grouping the problems conceptually reveals that different 'types' of problems emerge as more or less severe at different stages of the life-sentence.

Principal Components Analysis (PCA) was conducted on the severity data, in order to group the variables into small, but meaningful subsets of 'problems' (or 'dimensions') (rather than to identify latent 'constructs', as offered by Factor Analysis). Due to the distributions of the severity data being significantly non-normal for all problems (demonstrated by the Kolmogorov-Smirnov test, which was significant for all problems $-p<0.001$ ) (Field 2005), a 'normalizing (Blom) transformation' was conducted on the data. This adjusted the raw score values to allow for 'meaningful comparisons between tests' (Solomon and Sawilowsky 2009: 448), and to help with model selection (Hicks et al 2004: 924). PCA was subsequently conducted on the rank scores output. From the first analysis, ten factors emerged and four were retained due to their substantive importance, confirmed using Kaiser's criterion. Some changes were made to the extracted factors based on conceptual thinking (items were removed where they did not 'fit' conceptually, and were placed back into the analysis). The process of PCA was repeated on the remaining items (including those removed from the extracted factors), from which four further factors emerged. A final round of analysis was undertaken with eight items that had not 'fitted' conceptually elsewhere. This produced two further factors. Thus, the final nine dimensions, and one standalone item, emerged through an iterative process, involving reflection on both the theoretical grounding of the problem statements and the empirical knowledge derived through our fieldwork. A list of the dimension names, their respective Cronbach's alpha (standardized) reliabilities and the severity scores for each problem statement by sentence stage are shown in Tables 5-8.6

The results shown in Tables 5 to 8 demonstrate significant differences between prisoners at different sentence stages for problems clustered within the following themes: Deprivations, Autonomy/Control, and Time. The significant differences in the items within the Deprivations dimension were most commonly between the prisoners in the Post-Tariff group and prisoners in the Very Early and Early groups (see Table 3, above, for a detailed outline of each group), with some differences also found between the Very Early group and those at the Mid and Late stages of their sentence. That is, the particular hardships represented in this dimension missing little luxuries, missing social life, feeling sexually frustrated and missing somebody were experienced as most severe in the early stage of the sentence. This supports evidence presented elsewhere that initially adapting to imprisonment can be particularly gruelling (Liebling et al 2005b, Sapsford 1983). The challenges of negotiating the immediate and - for

\footnotetext{
${ }^{6}$ Note, the Cronbach's alpha score is not the same as the PCA factor loading score, which represents 'the regression coefficient of a variable for the linear model that describes a latent variable or factor' (Field 2005: 731).
} 
many in our study - unknown environment of the prison ${ }^{7}$ is also suggested by the significantly higher severity scores for those at the Very Early and Early stages (compared to the Post-Tariff group) for the Autonomy/Control dimension (e.g. 'finding it hard to keep out of trouble' and 'getting annoyed and irritated with other prisoners'). The results demonstrate the difficulty of learning to adapt to prison rules and living in an environment of strangers, although given that the severity scores for 'getting annoyed and irritated with other prisoners' is lower than for most other problems, Sykes' (1958: 77) observation that 'the worst thing about prison is having to live with other prisoners' is not borne out here.

The problems associated with Time were significantly different across a broader range of prisoner groups, with the mean dimension score being significantly higher (i.e. more severe) for prisoners at the Very Early stage compared to those at the Mid, Late and Post-tariff stages. Exploring this finding in more detail, the high severity scores for prisoners at the Very Early and Early stages for the problem 'feeling that the length of your sentence is unfair' is likely to reflect the high proportion of prisoners at these stages who were disputing their guilt, and appealing their convictions and/or sentences - a trend which declined according to sentence stage: $87 \%$ of Very Early stated that they were not guilty of the crime for which they were convicted, compared to $68 \%$ of Early, $44 \%$ of Mid, $48 \%$ of Late and 30\% of Post-Tariff prisoners; and $81 \%$ of Very Early prisoners were currently appealing their conviction and/or sentence, compared to $48 \%$ of Early, $24 \%$ of Mid, $14 \%$ of Late and 5\% of Post-Tariff prisoners. ${ }^{8}$ Similarly, 'thinking about the time you have left to serve' was significantly more severe for those at the Very Early and Early stage compared to those who were Post-Tariff. This is likely to reflect the reduced amount of time left before the tariff period is complete, at later sentence stages, as well as prisoners developing strategies to cope with the potentially overwhelming nature of time (Cohen and Taylor 1972; Flanagan 1981; Zamble 1992; Jamieson and Grounds 2002; O’Donnell 2014).

To summarise, then, the results of the most and least severe problems in our study were similar to those found in the preceding studies. However, in contrast to Richards' and Leigey and Ryder's findings - but in line with the broader literature on the experience of long sentences many problems appeared to be experienced as most severe by those at the earliest stage of the sentence, when the sudden encounter with the basic deprivations and lack of autonomy of prison life were felt especially sharply. These problems include some of the classic 'pains' of imprisonment related to the loss of goods and services, the loss of heterosexual relationships and the loss of autonomy (Sykes 1958), as well as concerns related to the 'abyss' (Cohen and Taylor 1972: 95) of time.

\footnotetext{
${ }^{7}$ For $56 \%$ of our sample, the life-sentence for which they were in prison was their first prison sentence. ${ }^{8}$ Although note that this data does not represent those who have appealed and their appeal has failed.
} 
Tables 5-8 - Survey dimensions, reliability scores and mean scores by sentence stage (asterisks show where scores for one group are significantly higher than for another group, depicted by their initials and shown in italics) ${ }^{9}$

\section{Table 5 - Deprivations}

\begin{tabular}{|c|c|c|c|c|c|c|}
\hline \multirow[b]{2}{*}{$\begin{array}{l}\text { Q. } \\
\text { no. }\end{array}$} & \multirow[b]{2}{*}{ DIMENSION (reliability)/question } & \multicolumn{5}{|c|}{ Mean Severity score (no. of respondents in each group) } \\
\hline & & $\begin{array}{c}\text { Very Early (VE) } \\
(50-58)\end{array}$ & $\begin{array}{c}\text { Early (E) } \\
(94-99)\end{array}$ & $\begin{array}{c}\text { Mid (M) } \\
(78-85)\end{array}$ & $\begin{array}{c}\text { Late (L) } \\
(26-28)\end{array}$ & $\begin{array}{c}\text { Post Tariff } \\
\text { (PT) } \\
(18-20)\end{array}$ \\
\hline & DEPRIVATIONS $(\alpha=.800)$ & $14.17 * * * \mathrm{PT}, * \mathrm{M}$ & $12.72 * * * \mathrm{PT}$ & $11.72 * \mathrm{PT}$ & 11.05 & 7.89 \\
\hline 20 & Wishing you had more privacy & 11.11 & 9.48 & 8.29 & 11.25 & 10.20 \\
\hline 24 & Missing little luxuries & $13.75^{* * * \mathrm{PT}}$ & $12.37^{* * * \mathrm{PT}}$ & $10.99 * * * \mathrm{PT}$ & $9.93 * * \mathrm{PT}$ & 5.35 \\
\hline 27 & Missing social life & $15.24 * * * \mathrm{PT}$ & $13.64^{* * \mathrm{PT}}$ & 11.95 & 10.93 & 7.70 \\
\hline 30 & Missing somebody & $19.55^{* * * \mathrm{PT}}$ & $17.19^{* * * \mathrm{PT}}$ & $17.56^{* * * \mathrm{PT}}$ & $17.14 * * \mathrm{PT}$ & 10.20 \\
\hline 33 & Feeling sexually frustrated & $12.71^{* * * \mathrm{PT}}$ & $12.23^{* * * \mathrm{PT}}$ & $11.70^{* * * \mathrm{PT}}$ & 9.14 & 6.05 \\
\hline 36 & Being bored & $12.25 * \mathrm{~L}$ & 11.61 & 9.38 & 7.93 & 7.85 \\
\hline
\end{tabular}

\section{Table 6 -Autonomy/Control}

\begin{tabular}{|l|l|c|c|c|c|c|}
\hline \multirow{2}{*}{$\begin{array}{l}\text { Q. } \\
\text { no. }\end{array}$} & DIMENSION (reliability)/question & \multicolumn{4}{|c|}{ Mean Severity score (no. of respondents in each group) } \\
\cline { 3 - 7 } & $\begin{array}{c}\text { Very Early (VE) } \\
(50-58)\end{array}$ & $\begin{array}{c}\text { Early (E) } \\
(94-99)\end{array}$ & $\begin{array}{c}\text { Mid (M) } \\
(78-85)\end{array}$ & $\begin{array}{c}\text { Late (L) } \\
(26-28)\end{array}$ & $\begin{array}{c}\text { Post Tariff } \\
(\text { PT) } \\
(18-20)\end{array}$ \\
\hline & AUTONOMY/CONTROL $(\alpha=.726)$ & $\mathbf{1 1 . 1 7 * * P T}$ & $\mathbf{1 0 . 8 0 * * \text { PT }}$ & $\mathbf{9 . 2 9}$ & $\mathbf{9 . 8 2}$ & $\mathbf{6 . 9 1}$ \\
\hline 25 & Finding it hard to keep out of trouble & $6.30^{* \mathrm{PT}}$ & $6.99^{* * * \mathrm{PT}}$ & 5.43 & 4.92 & 3.20 \\
\hline 31 & Getting annoyed or irritated with other prisoners & $10.35^{* \mathrm{PT}}$ & $10.05^{* \mathrm{PT}}$ & 8.68 & 10.00 & 6.70 \\
\hline 41 & Prison officers making life harder & $10.48^{* * \mathrm{PT}}$ & $10.98^{* * * \mathrm{PT}}$ & $9.44^{* * \mathrm{PT}}$ & $9.61^{* \mathrm{PT}}$ & 5.00 \\
\hline 42 & Feeling that you have no control over your life & 12.23 & 10.49 & 9.30 & 9.48 & 8.25 \\
\hline 57 & Having to follow other people's rules and orders & 16.47 & 15.32 & 13.51 & 15.07 & 11.74 \\
\hline
\end{tabular}

\footnotetext{
$9 * * * p<0.001, * * p<0.01, * p<0.05$
} 


\begin{tabular}{|c|c|c|c|c|c|c|}
\hline \multirow[b]{2}{*}{$\begin{array}{l}\text { Q. } \\
\text { no. }\end{array}$} & \multirow[b]{2}{*}{ DIMENSION (reliability)/question } & \multicolumn{5}{|c|}{ Mean Severity score (no. of respondents in each group) } \\
\hline & & $\begin{array}{c}\text { Very Early (VE) } \\
\quad(50-58)\end{array}$ & $\begin{array}{c}\text { Early (E) } \\
(94-99)\end{array}$ & $\begin{array}{c}\text { Mid (M) } \\
(78-85)\end{array}$ & $\begin{array}{r}\text { Late (L) } \\
(26-28)\end{array}$ & $\begin{array}{c}\text { Post Tariff } \\
\text { (PT) } \\
(18-20)\end{array}$ \\
\hline 37 & Feeling that you are losing the best years of your life & $17.09 * * \mathrm{PT}$ & $16.02 * \mathrm{PT}$ & 13.79 & 12.68 & 10.35 \\
\hline 45 & Feeling that the length of your sentence is unfair & $17.13^{* * * \mathrm{M}, \mathrm{L}, \mathrm{PT}}$ & $\begin{array}{l}14.97 * * * \mathrm{PT}, \\
* \mathrm{M}, \mathrm{L}\end{array}$ & 10.77 & 8.92 & 5.90 \\
\hline 54 & $\begin{array}{l}\text { Thinking about the amount of time that you might have } \\
\text { to serve }\end{array}$ & $13.70^{* \mathrm{PT}}$ & $13.16^{* \mathrm{PT}}$ & 12.29 & 13.15 & 8.17 \\
\hline
\end{tabular}

Table 8 - The remaining dimensions

\begin{tabular}{|l|l|c|c|c|c|c|}
\hline \multirow{2}{*}{$\begin{array}{l}\text { Q. } \\
\text { no. }\end{array}$} & DIMENSION/stand alone item (reliability) & \multicolumn{4}{|c|}{ Mean Severity score (no. of respondents in each group) } \\
\cline { 3 - 7 } & $\begin{array}{c}\text { Very Early } \\
(\text { VE) } \\
(50-58)\end{array}$ & $\begin{array}{c}\text { Early (E) } \\
(94-99)\end{array}$ & $\begin{array}{c}\text { Mid (M) } \\
(78-85)\end{array}$ & $\begin{array}{c}\text { Late }(\mathbf{L}) \\
(26-28)\end{array}$ & $\begin{array}{c}\text { Post Tariff } \\
(\text { PT }) \\
(18-20)\end{array}$ \\
\hline & RELEASE ANXIETY $(\alpha=.670)$ & $\mathbf{7 . 1 8}$ & $\mathbf{7 . 6 5}$ & $\mathbf{8 . 1 2}$ & $\mathbf{9 . 1 3}$ & $\mathbf{7 . 8 9}$ \\
\hline & PROGRESSION $(\alpha=.760)$ & $\mathbf{9 . 4 9}$ & $\mathbf{9 . 8 7}$ & $\mathbf{9 . 5 9}$ & $\mathbf{9 . 8 0}$ & $\mathbf{9 . 9 5}$ \\
\hline & ANGER/FRUSTRATION $(\alpha=.731)$ & $\mathbf{1 0 . 0 8}$ & $\mathbf{8 . 7 2}$ & $\mathbf{8 . 1 4}$ & $\mathbf{8 . 1 7}$ & $\mathbf{8 . 0 8}$ \\
\hline & EMOTIONAL AND PHYSICAL VULNERABILITY $(\alpha=.768)$ & $\mathbf{9 . 9 3}$ & $\mathbf{8 . 9 8}$ & $\mathbf{8 . 3 0}$ & $\mathbf{9 . 6 0}$ & $\mathbf{7 . 7 9}$ \\
\hline & MENTAL WELLBEING $(\alpha=.770)$ & $\mathbf{6 . 1 6}$ & $\mathbf{5 . 7 5}$ & $\mathbf{5 . 6 8}$ & $\mathbf{6 . 7 6}$ & $\mathbf{5 . 2 0}$ \\
\hline & OUTSIDE RELATIONSHIPS $(\alpha=.659)$ & $\mathbf{1 4 . 0 9}$ & $\mathbf{1 3 . 3 4}$ & $\mathbf{1 2 . 3 8}$ & $\mathbf{1 1 . 5 4}$ & $\mathbf{1 0 . 2 2}$ \\
\hline 39 & 'Thinking about the crime that you committed'10 & 8.53 & 13.76 & 12.78 & 13.31 & 12.54 \\
\hline
\end{tabular}

10 'While this statement is not formulated as a problem, as such, given its placement within a set of problem statements, we believe that it will have been interpreted in this manner (as a 'negative' issue). Only prisoners who expressed that they were guilty of the offence for which they were convicted, earlier in the survey, were asked to respond to this question. 


\section{Discussion}

In previous studies, the overall consistency of severity scores across sentence stages has been interpreted as indicative of prisoners' ability to adapt to, and cope with, the prison environment. Leigey and Ryder (2014: 12) report that prisoners grow 'accustomed' to separation from family and develop 'strategies to help cope' with the lack of privacy. Flanagan (1981) describes 'attitudinal' and behavioural changes in the long-term prisoner that help him avoid trouble, as well as to cope with the problems of time, relationships with other (younger) prisoners, and 'getting things done'. Sapsford (1983: 72) similarly discusses the way in which individuals respond to an environment by reinterpreting their expectations of it, so that the meaning of 'situations' is 'reconstructed' 'in order to render life more tolerable'. In turn, Zamble (1992: 42) suggests that the initial pains of imprisonment are alleviated by the consistency of prison life: 'the beginning of the term induces considerable psychological discomfort but the constancy of the prison environment leads to a slow and gradual amelioration'. The key point of such conclusions is not that prisoners' 'objective' experiences of imprisonment change (so that family contact improves, as such, or the prisoner is granted a greater degree of autonomy), but that prisoners' subjective interpretations of their problems, circumstances and environment change:

The main outcome of the longitudinal analysis is that prisoners did not deteriorate, because they found ways of coming to terms with the prison environment and using it for their own purposes [...] [Most men] managed to reassert some measure of control over their prison experience and a few managed effectively to 'negate' or 'escape from' it by forcing a redefinition of circumstance such that prison was an inconvenience rather than an environment exerting total control, or even became a facilitating environment.

(Sapsford 1983: 63)

Improved coping techniques are part of the process of adapting to prison life for all prisoners (Sykes 1958; Crewe 2009). To survive long-term imprisonment in particular, the prisoner must find ways to cope (Sapsford 1983). Life-sentenced prisoners learn to do 'time', both through their direct experiences and their interactions with other prisoners, who transmit useful coping techniques, including self-sufficiency and a focus on the present (Sapsford 1983; Flanagan 1981).11 It is this notion of 'normal adaptation' that is typically used to explain the lack of accumulation of the problems of long-term imprisonment over time (Richards 1978; Leigey and Ryder 2014).

In this orthodox reading of prison adaptation, the implication is that, while the prisoner redefines the problem environment, he himself remains in essence the same. Our interpretation of what is essentially the same data pattern is somewhat different, for it is more plausible that imprisonment over many years alters the prisoner in ways that are profound and enduring. To make this case is not to suggest that prisoners become 'institutionalised', in the way that the

\footnotetext{
${ }^{11}$ Note that there are obviously exceptions, people who fail to cope at all, such as those described by Sapsford (1983: 86) and indicated by those who take their own life and the approximately 200 men and women (out of just over 1000 who matched our overall research sampling criteria) who had been transferred to and detained in hospital under section 47/49 of the Mental Health Act 1983 (or its equivalent of the 1959 Act) during their life-sentence (L. McKean, personal communication,29 January, 2014).
} 
term has been conventionally adopted: that is, psychologically dependent upon the institution (Sapsford 1978). Rather, it is to suggest that the very coping mechanisms that aim to alleviate some of the pains and problems of imprisonment might, as a secondary effect, be deeply transformational and in some sense debilitating. Recent findings by Liem and Kunst (2013) support this interpretation. Their research identified in prisoners who had experienced 'prolonged incarceration' (Liem and Kunst 2013: 333) a specific cluster of psychological symptoms, referred to as 'Post-Incarceration Syndrome (PICS), which were similar to the indicators of Post-Traumatic Stress Disorder (PTSD), but with three supplementary characteristics: 'institutionalised personality traits (distrusting others, difficulty engaging in relationships, hampered decision-making), social-sensory disorientation (spatial disorientation, difficulty in social interactions) and social and temporal alienation (the idea of 'not belonging' in social and temporal settings)' (Liem and Kunst 2013: 336).

Certainly, in interviews, many prisoners told us that they had undergone significant and sometimes wholesale personal transformations, or described traits reflective of those described in the PTSD and PICS literature. One such characteristic was 'emotional numbing', which Liem and Kunst (2013: 335) summarise as a coping mechanism which creates 'a permanent and unbridgeable distance between themselves and other people.'

'I think what jail does do, and it naturally does it, especially when you are doing a long time, it does harden you. It does make you a bit more distant, because it just is, that's the life you are in. [...], you are not going to see it in jail, people being all emotional and touchy feely and expressing their emotion, it doesn't happen. So for people in this situation you see it even less, people hold it all in. People keep that to themselves. And so I think that's just sadly a part of prison. It is who you become, and if you are hardened in the beginning then you become even harder, you become even colder, you become more detached.' (Joseph)

A second (related) characteristic was manifested in distrust of others, and difficulties in social interaction (see also Schinkel 2014):

You've gotta be more cold in prison.

[...]Why d'you need to be cold with people? Why can't you be as friendly with people? It's jail, man. You can't even trust anyone like that. (Samuel)

My friends say on a visit that I'm not me anymore, and when I ask them they say 'you've changed. It's not good but it's not bad. You're just there, you're just existing'. [...]

What do they mean, exactly?

[...]... I was always there for people when they needed me and everything, and it's, sort of, changing a bit now. I don't want to be around people. (Paul)

Prisoners in our study also expressed feelings of vulnerability, as identified in the PICS literature:

And d'you think that being a long term prisoner has changed you as a person?

Yeah.

In what way?

It's... I, kind of, don't have feelings for people. Like, I don't feel safe no more. I don't know why. I used to.

Was that the sentence or the offence or the...?

The sentence. (Hugo) 
All of this is to suggest two things. The first is that that the reduction of problem severity according to sentence stage may reflect forms of coping which fundamentally transform the self. The second is that such a transformation may in itself be damaging. Issues that are initially encountered as 'problems' are no longer experienced as such, because the requirements of coping and survival so deeply reshape the prisoner's identity. ${ }^{12}$ The everyday pains of imprisonment are 'felt' less sharply, because, in some senses, they have been internalised into the prisoner's being, and have made him or her become a different person. The prisoner is 'permanently changed' (Haney 2003: 38): to quote a prisoner cited by Flanagan (1981: 210), '...after 12 years, you ain't the same [person]'. The conceptual distinction between 'self' and 'problem' no longer holds: the former has become adjusted to the constant presence of the latter. And as the long-term prisoner becomes 'adapted' - in the true sense of the term - to the imperatives of a sustained period of confinement, he or she becomes more emotionally detached, more self-isolating, more socially withdrawn, and perhaps less well suited to life after release.

\section{Conclusion}

The consistent findings of quantitative studies of the problems of long-term imprisonment are open to two interpretations. The first, as per Flanagan (1980) and Leigey and Ryder (2014), is that problems do not accumulate: prisoners are able to alleviate the problems of imprisonment due to changes in their interpretation of these problems and their responses to them. In this reading of the data, the adaptation process is attitudinal, superficial (in that it does not deeply affect the individual) and productive (as it makes prison more survivable). Indeed, for some long-term prisoners, the experience of extreme imprisonment may even be defined as potentially enlightening, allowing them to flourish (O'Donnell 2014). A second interpretation is that adaptation to long-term imprisonment has a deep and profound impact on the person so that the process of coping leads to fundamental changes in the self, which go far beyond the attitudinal, and may bring about secondary problems of their own.

Both interpretations have implications beyond the prison environment. If prisoners' responses to their (long-term) incarceration are primarily attitudinal, these changes may be protective and transient (rather than embedded and unremitting) (O'Donnell 2014). The suggestion is that the prisoner's core self is in 'deep-freeze', and that, on release, when the external environment changes, prisoners can successfully re-adjust their attitudes to the needs of the outside world (Schmid and Jones 1991; O’Donnell 2014; Zamble and Porporino 1988).

In comparison, if the prisoner is changed fundamentally by their experience of imprisonment, the implications for release are more complex and concerning. As Haney (2003) notes, the 'normal adaptations' employed to counter the 'abnormal' prison environment may have adverse effects. Such adaptations, as evidenced by Liam and Kunst (2013), include hypervigilance, estrangement, the denial of intimacy, withdrawal, self-isolation, the suppression of emotion, avoidance of communication and a distrust of the world (Grounds 2005; Haney 2003). These can become 'deeply internalised so that, even though surrounding conditions may change, many of the once-functional but ultimately counterproductive patterns remain' (Haney 2003: 39). While these changes are 'adaptive' in the hostile, controlled, and limiting environment of the

${ }^{12}$ Those problems that do feel more severe only become salient relatively late in the sentence. 
prison, they may well be maladaptive on release, within social and family life (Grounds 2005), and within a social world that is considerably less threatening than the prison. The final implication relates to the essence of imprisonment itself. The similarities between the results from the four studies compared in this paper are striking, particularly given that they were conducted in different countries and over a period of 36 years. They suggest that, almost regardless of time, place and policy context, the deprivation of liberty over a sustained period of time creates certain kinds of pains, and certain patterns of adaptive reaction, that are relatively consistent. We do not believe that the consistency of these problems would hold regardless of context, nor that their intensity would not vary considerably. Neither do we think that they suggest that prisons should give up on the task of meeting the needs of long-term prisoners. Rather, they require prison administrators to recognise the depth and intractability of the problems that they need to manage and alleviate when dealing with the men and women who are subject to state punishment at its most extreme.

\section{Funding information}

This work was supported by the Economic and Social Research Council [grant: ES/J007935/1]. 


\section{References}

Bukstel, L. H., \& Kilmann, P. R. (1980), 'Psychological effects of imprisonment on confined individuals', Psychological Bulletin, 88/2: 469-493.

Cohen, S. and Taylor, L. (1972), Psychological survival: The experience of long-term imprisonment. Harmondsworth: Penguin Books Ltd.

Crawley, E. and Sparks, R. (2006), 'Is there life after imprisonment? How elderly men talk about imprisonment and release', Criminology and Criminal Justice, 6/1: 63-82.

Crewe, B. (2009), The prisoner society: Power, adaptation and social life in an English Prison. Oxford: Oxford University Press.

Crewe, B. (2011), 'Depth, weight and tightness: Revisiting the pains of imprisonment', Punishment and Society, 5: 509-529.

Crewe, B., Hulley, S., and Wright, S. (in progress), 'Adaptation to long-term imprisonment'.

Dettbarn, E. (2012), 'Effects of long-term incarceration: A statistical comparison of two expert assessments of two experts at the beginning and the end of incarceration', International Journal of Law and Psychiatry, 35/3: 236-239.

Feeley, M. M. and Simon, J. (1992), 'The New Penology: Notes on the emerging strategy of corrections and its implications', Criminology, 30/4: 449-474.

Field, A. (2005), Discovering Statistics Using SPSS, 2nd Edition. London: Sage.

Flanagan, T.J. (1980), 'The pains of long-term imprisonment: A comparison of British and American Perspectives', British Journal of Criminology, 20/2: 148-156.

Flanagan, T.J. (1981), 'Dealing with long-term confinement: Adaptive strategies and perspectives among long-term prisoners', Criminal Justice and Behaviour, 8: 201-222.

Flanagan, T.J. (1995), 'Long-term incarceration: Issues of science, policy and correctional practice', in T.J Flanagan, ed., Long-term imprisonment: Policy, science, and correctional practice, 3-9. Thousand Oaks: Sage Publications.

Grounds, A. (2005), 'Understanding the effects of wrongful imprisonment', Crime and Justice, 32: 1-58.

Haney, C. (2003), 'The psychological impact of incarceration: Implications for postprison adjustment', in J. Travis and M. Waul, eds. Prisoners once removed: The impact of incarceration on children, families and communities, 33-66. Washington: The Urban Institute Press.

Hefferon, K., Grealy, M. and Mutrie, N. (2009), 'Post-traumatic growth and life threatening physical illness: A systematic review of the qualitative literature', British Journal of Health Psychology, 14: 343-378.

Hicks, B.M. Krueger, R.F., Iacono, W.G., McGue, M. and Patrick, C.J. (2004), 'Family Transmission and Heritability of Externalizing Disorders', Archives of General Psychiatry, 61: 922-928. 
Hough, M., Jacobson, J. and Millie, A. (2003), The decision to imprison: Sentencing and the prison population. London: Prison Reform Trust.

Hollway, W., \& Jefferson, T. (2000), Doing qualitative research differently: Free association, narrative and the interview method. London: Sage Publications.

Jameison, R. and Grounds, A. (2002), No Sense of an ending: The effects of long-term imprisonment amongst Republican prisoners and their families. Monaghan: SEESYU Press Ltd.

Jewkes, Y. (2005), 'Loss, liminality and the life sentence: Managing identity through a disrupted lifecourse', in A. Liebling, \& S. Maruna, eds., The effects of imprisonment, 366-388. Cullompton: Willan Publishing.

Johnson, R. and McGunigall-Smith, S. (2008), 'Life Without Parole, America's other death penalty: Notes on life under sentence of death by incarceration', The Prison Journal, 88/2: 328346.

King, R.D. (2005), 'The effects of supermax custody', in A. Liebling and S. Maruna, eds., The effects of imprisonment, 118-145. Cullompton: Willan Publishing.

Lapornik, R., Lehofer, M., Moser, M., Pump, G., Egner, S., Posch, C., Hildebrandt, G. and Zapotoczky, H.G. (1996), 'Long-term imprisonment leads to cognitive impairment', Forensic Science International, 82: 121-127.

Leigey, M.E. and Ryder, M.A. (2014), 'The pains of permanent imprisonment: Examining perceptions of confinement among older Life Without Parole inmates', International Journal of Offender Therapy and Comparative Criminology, 1-17.

Liebling, A. and Arnold, H. (2012), 'Social relationships between prisoners in a maximum security prison: violence, faith, and the declining nature of trust', Journal of Criminal Justice, 40/5: 413-424.

Liebling, A, Arnold, H. and Straub, C. (2012), An Exploration of Staff-Prisoner Relationships at HMP Whitemoor: Twelve Years On, London: National Offender Management Service.

Liebling, A. Durie, L., Stiles, A. and Tait, S. (2005a), 'Revisiting prison suicide: the role of fairness and distress', in A. Liebling, and S. Maruna, eds., The effects of imprisonment. 209-231. London: Routledge.

Liebling, A., Tait, S., Durie, L., Stiles, A. and Harvey, J. (2005b), An evaluation of the Safer Custody Programme: Final Report. Cambridge: Cambridge Institute of Criminology. Accessed 9.12.14 from http://www.crim.cam.ac.uk/people/academic_research/alison_liebling/SaferCustodyReport.pd $\mathrm{f}$

McAdams, D. (1988), 'Biography, narrative, and lives: An introduction', Journal of Personality, 56/1: $1-18$.

O’Donnell, I. (2014), Prisoners, Solitude and Time. Oxford: Oxford University Press. 
Rasch, W. (1981), 'The effects of indeterminate detention: A study of men sentenced to life imprisonment', International Journal of Law and Psychiatry, 4: 417-431.

Rhodes, L.A. (2004), Total confinement: Madness and reason in the Maximum Security prison. Berkeley and Los Angeles: University of California Press Ltd.

Richards, B. (1978), 'The experience of long-term imprisonment', British Journal of Criminology, 18/2: 162-169.

Sapsford, R. (1978), Life-sentence prisoners: Psychological changes during sentence, British Journal of Criminology, 18/2: 128-145.

Sapsford, R. (1983), Life sentence prisoners: Reaction, response and change. Milton Keynes: Open University Press.

Schinkel, M. (2014), Being Imprisoned: Punishment, adaptation and Desistance. London: Palgrave Macmillan.

Schmid, and Jones, (1991), 'Suspended identity; Identity transformation in a maximum security prison', in D.M. Newman, ed., (2000). Sociology: Exploring the Architecture of Everyday Life (Readings). Thousand Oaks, CA: Pine Forge Press.

Shammas, V.L. (2014), "The pains of freedom: Assessing the ambiguity of Scandinavian penal exceptionalism on Norway's Prison Island', Punishment and Society, 16/1: 104-123.

Solomon, S.R., and Sawilowsky, S.S. (2009), 'Impact of rank-based normalizing transformations on the accuracy of test scores', Journal of Modern Applied Statistical Methods, 8/2: 448-462.

Sykes, G.M. (1958), The society of captives: A study of a maximum security prison. New Jersey: Princeton University Press.

Wacquant, L. (2009), Punishing the poor: The neoliberal government of social insecurity. Durham, NC: Duke University Press.

Walker, N. (1987), The unwanted effects of long-term imprisonment, in A. E. Bottoms, \& R. Light, Problems of long-term imprisonment, 183-199. Aldershot: Gower.

Wright, S., Crewe, B. and Hulley, S. (under review), 'Suppression, denial, sublimation: Adapting to the early phase of very long life sentences'.

Zamble, E. (1992), 'Behaviour and adaptation in long-term inmates: Descriptive longitudinal results', Criminal Justice and Behaviour, 19: 409-425.

Zamble, E. and Porporino, F. J. (1988), Coping, behavior, and adaptation in prison inmates. New York: Springer-Verlag Publishing. 